\title{
Metals Phytoextraction by Cordia africana from Soils Contaminated with Oil Drilling Waste
}

\author{
Nelson Moura Brasil do Amaral Sobrinho ${ }^{1}$ (D) 0000-0002-5053-7338 \\ André Fernão Martins de Andrade ${ }^{2}$ (1) 0000-0003-0193-3198 \\ Erica Souto Abreu Lima' ${ }^{1}$ (1) 0000-0003-4140-3634 \\ Everaldo Zonta ${ }^{1}$ (1) 0000-0001-8106-0504 \\ Márcio Osvaldo Lima Magalhães 3 [1] 0000-0001-8599-2982
}

\begin{abstract}
Oil exploration and production generate large quantities of waste, which may contain contaminants such as barium and lead. Therefore, more studies aimed at decreasing the levels of heavy metals in contaminated sites, using methods such as phytoremediation, are needed. In a preliminary assay, samples of soil contaminated with oil drilling waste were incubated with different concentrations $\left(2\right.$ or $\left.6 \mathrm{mmol} \mathrm{L}^{-1}\right)$ of ethylenediaminetetraacetic acid (EDTA). Subsequently, an experiment was conducted in a greenhouse to evaluate the phytoremediation potential of the tree Cordia africana. EDTA induced mobilization and translocation of lead, manganese, and iron into the C. africana leaves but had no effect on barium. The quantity of heavy metal contaminants accumulated in the plant vegetative parts showed that C. africana cannot be used as a phytoextractor for the tested metals; however, it can be used as a phytostabilizer.
\end{abstract}

Keywords: contamination, phytoremediation, heavy metals, EDTA.

\section{INTRODUCTION AND OBJECTIVES}

The search for alternative energy sources to fossil fuels, which began in the late 1990s, has not decreased the permanent search for oil and gas. The search for new oil and gas fields in Brazil and worldwide has been increasing and may generate large amounts of waste, requiring adequate disposal and/or treatment sites (Bauder et al., 2005).

Oil exploration generates wastes from well drilling, and these wastes have polluting potential and are mainly constituted by fragmented rocks mixed with drilling fluid. These pollutants contain hydrocarbons and heavy metals such as iron, manganese, lead, and, especially, barium (Magalhães et al., 2014; Sampaio et al., 2015).

Drilling fluid is a circulating fluid used to aid perforation Its main functions are to maintain the stability of the borehole, remove cuttings from the borehole, prevent the inflow of fluids from the permeable rocks that are penetrated, and control the formation pressures and the concentration of suspended particulate matter (Caenn et al., 2011). Among the products used in this fluid, barite, or natural barium sulfate (BaSO4), stands out due to its high density, but other heavy metals are also commonly present (Lima et al., 2012).

The aim of phytoremediation is to remove part of the contaminants in the soil and/or to stabilize contaminants remaining in the soil in small labile forms, decreasing the possibility of leaching and consequent groundwater contamination (Neugschwandtner et al., 2008).

The plants selected for phytoremediation can sometimes only be used in large heavy metal-polluted areas after the soil contaminant levels decrease to phytotoxicity thresholds. A combined approach with the goal of immobilizing or removing contaminants, followed by a ground cover, would be promising to recover the biological activity of soils (Evangelou et al., 2007).

Pereira et al. $(2012,2013)$ observed a high tolerance of Cordia africana to high concentrations of heavy metals, such as

\footnotetext{
${ }^{1}$ Universidade Federal Rural do Rio de Janeiro (UFRRJ), Seropédica, RJ, Brasil

${ }^{2}$ Instituto Federal de Educação, Ciência e Tecnologia do Rio de Janeiro (IFRJ), Pinheiral, RJ, Brasil

${ }^{3}$ Universidade do Estado do Mato Grosso (UNEMAT), Tangará, MT, Brasil
} 
zinc, cadmium, and lead, thereby showing the plant's potential for phytostabilization. Cordia africana is a semideciduous tree native to Africa, approximately $10 \mathrm{~m}$ high. It belongs to the family Boraginaceae and has simple leaves, long branches, axillary and terminal inflorescences with white flowers, and flowers in the spring (Lorenzi et al., 2003).

Soil contamination with the heavy metals usually contained in oil well drilling and prospecting wastes has been investigated in a site that has been used for the disposal of these wastes for more than 20 years, located in Santa Maria do Oeste, Paraná, Brazil (Andrade et al., 2014).

The aim of this study was to investigate EDTA-induced phytoextraction by C. africana from soil contaminated with oil well drilling and prospecting wastes.

\section{MATERIALS AND METHODS}

The contaminated soil consisted of a mix of deposited oil well drilling and prospecting wastes and local soil (Red Latosol; Oxisol, according to the USDA soil classification) with the following composition: $52 \%$ silt, $38 \%$ sand, and $10 \%$ clay (Donagema et al., 2011).

The soil presented a high concentration of base cations, with $9.5 \mathrm{cmol}_{c} \mathrm{dm}^{-3} \mathrm{Ca}$ and $2.0 \mathrm{cmol}_{c} \mathrm{dm}^{-3} \mathrm{Mg}$, an approximate $\mathrm{pH}$ of 8.3 , and a carbon concentration of $1.4 \mathrm{~g} \mathrm{~kg}^{-1}$. The soil barium, lead, manganese, and iron concentrations were 6,700, 570,614 , and $30,319 \mathrm{mg} \mathrm{kg}^{-1}$ soil, respectively.

To investigate the effect of EDTA on the heavy metal geochemical fractions, 15 plastic pots were filled with $100 \mathrm{~g}$ of contaminated soil and incubated with or without two EDTA concentrations ( 2 or $6 \mathrm{mmol} \mathrm{L}^{-1}$ ) for 120 days with five replicates per treatment.

After incubation, a soil sample was collected and air-dried, and the concentrations of the studied heavy metals in the different geochemical fractions were analyzed. A sequential extraction method was used, according to Ure et al. (1993) and modified by Rauret et al. (1999), to separate the extractable metals into the following four fractions:

- Acid soluble and/or, specifically, exchangeable fraction $(\mathrm{F} 1)=0.11 \mathrm{~mol} \mathrm{~L}^{-1} \mathrm{CH}_{3} \mathrm{COOH}$. Samples of $1 \mathrm{~g}$ of soil were placed in Falcon centrifuge tubes, $40 \mathrm{~mL}$ of $0.11 \mathrm{~mol} \mathrm{~L}^{-1}$ acetic acid was added, and the tubes were shaken in a horizontal shaker for 20 hours. The samples were then centrifuged for 15 minutes at $3000 \mathrm{rpm}$. The supernatant was removed, and the pellet was washed with deionized distilled water, before the addition of the following extraction solution. The washing procedure consisted of adding $10 \mathrm{~mL}$ of deionized water to each tube, shaking the tubes for 15 minutes, and centrifuging them for phase separation. The supernatant was removed and added to the supernatant resulting from the first extraction, and distilled water was added to the mix to obtain a final volume of $50 \mathrm{~mL}$.

- Oxide-bound fraction (F2) $=0.1 \mathrm{~mol} \mathrm{~L}^{-1} \mathrm{NH}_{2} \mathrm{OH} . \mathrm{HCl}$, $\mathrm{pH}=2$. Forty milliliters of $0.1 \mathrm{~mol} \mathrm{~L}^{-1}$ hydroxylamine was added to the washed pellet, shaken for 20 hours, and centrifuged for 15 minutes at $3000 \mathrm{rpm}$. The supernatant was removed, and the pellet was washed as described for the first extraction. Distilled water was added to the supernatant to obtain a final volume of $50 \mathrm{~mL}$.

- Organic matter-bound fraction $(\mathrm{F} 3)=8.8 \mathrm{~mol} \mathrm{~L}^{-1} \mathrm{H}_{2} \mathrm{O}_{2}$ $+1 \mathrm{~mol} \mathrm{~L}^{-1} \mathrm{CH}_{3} \mathrm{COONH}_{4}, \mathrm{pH}=2.0$. Ten milliliters of $8.8 \mathrm{~mol} \mathrm{~L}^{-1}$ hydrogen peroxide was added to the washed pellet resulting from the second extraction and incubated for 1 hour at room temperature with occasional manual shaking. The samples were placed in a water bath at $85^{\circ} \mathrm{C}$ until the volume was reduced to $23 \mathrm{~mL}$. Next, $10 \mathrm{~mL}$ of "C" solution was added to each tube, and the tubes were again placed in the water bath until the volume was reduced to $23 \mathrm{~mL}$; $50 \mathrm{~mL}$ of $1.0 \mathrm{~mol} \mathrm{~L}^{-1}$ ammonium acetate was then added, as described for the previous extractions.

- Residual fraction $(\mathrm{F} 4)=$ Pseudo-total metal contents $(\mathrm{F} 1+\mathrm{F} 2+\mathrm{F} 3)$. Determination of pseudo-total metal contents (aqua regia): $1 \mathrm{~g}$ of soil was placed in a glass tube containing $1 \mathrm{~mL}$ of deionized water, $7 \mathrm{~mL}$ of $12 \mathrm{~mol} \mathrm{~L}^{-1} \mathrm{HCl}$ was added, followed by $2.3 \mathrm{~mL}$ of $15.8 \mathrm{~mol} \mathrm{~L}^{-1} \mathrm{HNO}_{3}$, drop by drop, to remove the foam formed, and the mixture was allowed to stand for $18 \mathrm{~h}$ at room temperature for slow oxidation of the soil organic matter. After cooling, the solution was filtered using a Millipore filter $(0.45 \mu \mathrm{m}$ pore $)$, and deionized water was added to obtain a final volume of $50 \mathrm{~mL}$.

The experiment was conducted in a greenhouse at Federal Rural University of Rio de Janeiro (Universidade Federal Rural do Rio de Janeiro - UFRRJ). Contaminated soil collected in Santa Maria do Oeste, Paraná, Brazil, was used as the growth substrate for C. africana.

Three treatments were tested: control, which received only deionized water and nutrients, and two treatments with a single application of either 2 or $6 \mathrm{mmol} \mathrm{L}^{-1}$ EDTA. Five replicates were performed per treatment, yielding 15 experimental units. 
Seedlings (200 days old) were transferred to pots with $4 \mathrm{~kg}$ of soil contaminated with oil well drilling and prospecting waste. The seedlings selected were as homogeneous as possible: approximately $70 \mathrm{~cm}$ in height and between 0.93 ; and $1.14 \mathrm{~cm}$ in stem diameter at $5 \mathrm{~cm}$ above ground, with 17-19 leaves. One seedling was planted per pot, resulting in 15 plants. Soil moisture was maintained at $80 \%$ field capacity throughout the experiment. Plants received nutrient solution (25\% Hoagland) starting at 30 days after the plant transfer into the pots.

Four C. africana seedlings were collected before planting, and the barium, lead, manganese, and iron concentrations in the leaves, stems, roots, and substrate were quantified to determine naturally occurring concentrations in the seedlings before their transfer into the substrate and in the substrate. EDTA was applied to plants 250 days after sowing. The EDTA treatments consisted of $2 \mathrm{mmol} \mathrm{L}^{-1}$ or $6 \mathrm{mmol} \mathrm{L}^{-1}$ applied in a single dose.

Three months following the EDTA application, the plants were harvested (shoot and root) for analysis of the metal uptake by the plants. The plants were separated into root, main stem, secondary stems and leaves. The substrate was separated from the plant and stored in plastic bags for subsequent air drying and chemical analyses. The plants were washed in running water for the removal of macroscopic material and separated into roots and shoots, and the plant parts were washed with deionized water. The plants were air dried and put in a drying oven at $70{ }^{\circ} \mathrm{C}$ until a constant weight was achieved. The dry material was ground through a 20-mesh sieve in a Wiley mill and digested according to the USEPA 3050B method.

The metal accumulation and translocation index (TI) were calculated with dry weights for each plant part. TI is the ratio between the total content of a given element in the shoot and its total content in the whole plant; that is, it is the percentage content translocated from roots into leaves and stems (Abichequer \& Bohnen, 1998).

The barium, lead, manganese, and iron concentrations in the soil and plant extracts were quantified by inductively coupled plasma optical emission spectrometry (ICP-OES) using a Perkin Elmer Optima 3000 plasma emission spectrometer, with a detection limit (DL) of $0.036 \mathrm{mg} \mathrm{kg}^{1}$ for barium, $0.25 \mathrm{mg} \mathrm{kg}^{1}$ for lead, $0.20 \mathrm{mg} \mathrm{kg}^{1}$ for iron, and $0.30 \mathrm{mg} \mathrm{kg}^{1}$ for manganese and a quantification limit (QL) of $0.36 \mathrm{mg} \mathrm{kg}^{1}$ for barium, $0.5 \mathrm{mg} \mathrm{kg}^{1}$ for lead, $0.7 \mathrm{mg} \mathrm{kg}^{1}$ for manganese, and $0.4 \mathrm{mg} \mathrm{kg}^{1}$ for iron. The DL was calculated as the average blank value plus three times its standard deviation for all analyses (10 replicates). The measurements of the pseudototal concentrations of barium, lead, manganese, and iron in the soil and plants were validated by an analysis of the following certified reference materials: NIST SRM 2709a San Joaquin Soil, presenting $979 \pm 28 \mathrm{mg} \mathrm{kg}^{-1}$ barium (95\% recovery), $17.3 \mathrm{mg} \mathrm{kg}^{-1}$ lead (92\% recovery), $539 \mathrm{mg} \mathrm{kg}^{-1}$ manganese (94\% recovery), and 33,600 mg kg ${ }^{-1}$ iron (89\% recovery); SRM 1573a - tomato leaves with $63 \mathrm{mg} \mathrm{kg}^{-1}$ barium (93\% recovery), $246 \mathrm{mg} \mathrm{kg}^{-1}$ manganese (92\% recovery), and $368 \mathrm{mg} \mathrm{kg}^{-1}$ iron (95\% recovery); and SRM 1547 - peach leaves with $0.87 \mathrm{mg} \mathrm{kg}^{-1}$ lead (90\% recovery). The values obtained for the reference materials were within the ranges accepted by the National Institute of Standards and Technology (NIST) as normal for soil and plant samples.

An analysis of variance was performed using the F-test $(\rho<0.05)$, followed by Tukey's test $(p<0.05)$, with SAS ${ }^{\circledast} 9.2$ software (SAS Institute Inc., Cary, NC, USA).

\section{RESULTS AND DISCUSSION}

The geochemical fractionation of soil samples was analyzed following sample incubation with 0,2 , and $6 \mathrm{mmol} \mathrm{L}^{-1} \mathrm{EDTA}$ for 120 days. Statistically significant differences were observed in the barium content of F2 fractions (Figure 1a), indicating that the EDTA concentrations tested were not sufficient to promote a pronounced dissolution of the less labile fractions.

Overall, the application of 2 or $6 \mathrm{mmol} \mathrm{L}^{-1}$ EDTA had little effect on the geochemical fractionation of barium, lead, manganese, and iron compared to the control treatment.

Barium was almost exclusively detected in the most recalcitrant fraction (F4), with only small concentrations being observed in the remaining soil fractions (Figure 1).

Although the barium contents in the F2 fractions were statistically significantly different between the different treatments, the differences were numerically small. The observed low barium concentrations and the labile forms confirm the low solubility of barite, which is composed mainly of barium sulfate (Sposito, 2008) and is a component of the drilling fluid.

Approximately $10 \%$ of the total lead was detected in F1 (exchangeable and carbonate bound), and approximately $30 \%$ in F2 (Figure $1 \mathrm{~b}$ ). The binding of lead with carbonates and oxides was previously reported by Pichtel et al. (2000), and Xia et al. (2009) showed that lead has high affinity for Fe oxides, especially manganese oxides.

No significant differences in $\mathrm{Pb}$ were observed with the EDTA addition for fraction F1 (Tukey test at $\mathrm{p}<0.05$; Figure 1b). This result is in contrast with the results of Pereira et al. (2010), who observed a pronounced increase in the lead in a soil solution with the addition of $0.5 \mathrm{~g} \mathrm{~kg}^{-1}$ EDTA. The increase in EDTA concentration had no significant effect on the geochemical fractionation of lead.

High manganese concentrations were observed for fractions F1 and F2 (Figure 1c), showing higher Mn lability 
in the fraction containing iron and manganese oxides, which were present both in more reducible and amorphous forms.

Silveira et al. (2006) showed that the sequential extraction method used in the present study allows for a part of these oxides to be detected as a part of F4, indicating that they are less soluble than they appear.

The high quantity of manganese recovered in F2 was likely correlated with the high quantity of lead in this fraction (almost 30\%) due to the high lead affinity for manganese oxides (Ma \& Uren, 1998).

Iron was the analyzed metal with higher percentage in fraction F4, being practically absent from F1 (Figure 1d). However, a significant increase in iron was found in $\mathrm{F} 1$ with the application of $6 \mathrm{mmol} \mathrm{L}^{-1} \mathrm{EDTA}$. This may have been due to the dissolution of iron and it's binding with EDTA as a result of the high stability constant of iron-EDTA complexes $\left(1.4 \times 10^{25}\right)$. Vaxevanidou et al. (2008) observed partial dissolution of crystalline iron oxides in soil incubated with $300 \mathrm{mmol} \mathrm{L}^{-1}$ EDTA.
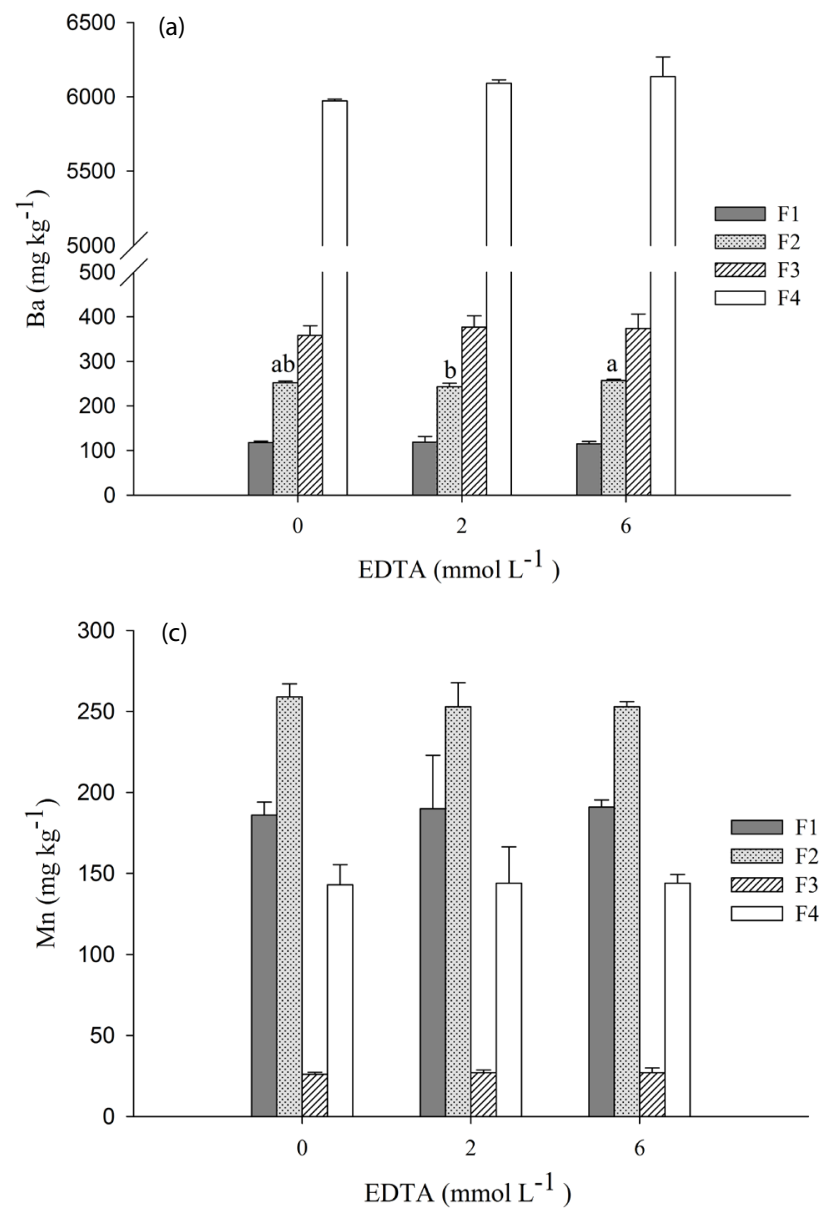

After plant transfer, plant height and diameter quickly increased. The growth in height decreased during the colder months, but the stem continued to thicken until plant harvesting.

No significant differences in the dry matter production of the leaf, main and secondary stems, or root of C. africana were observed. However, a tendency for lower dry matter production with the highest EDTA dose was observed. Statistically significant differences were only observed for the total plant dry weight between the $6 \mathrm{mmol} \mathrm{L}^{-1}$ EDTA-treated plants and the control plants, followed by the treatment with $2 \mathrm{mmol} \mathrm{L}^{-1}$ EDTA (Table 1). Significantly higher dry matter production in the control plants than in the plants with EDTA application has been previously observed in Brachiaria and corn, indicating EDTA toxicity to plants (Santos et al., 2006). Neugschwandtne et al. (2008) found visible toxicity symptoms with the application of higher EDTA doses ( 6 and 9 mmol kg ${ }^{1}$ EDTA), causing plant death before the harvest time.
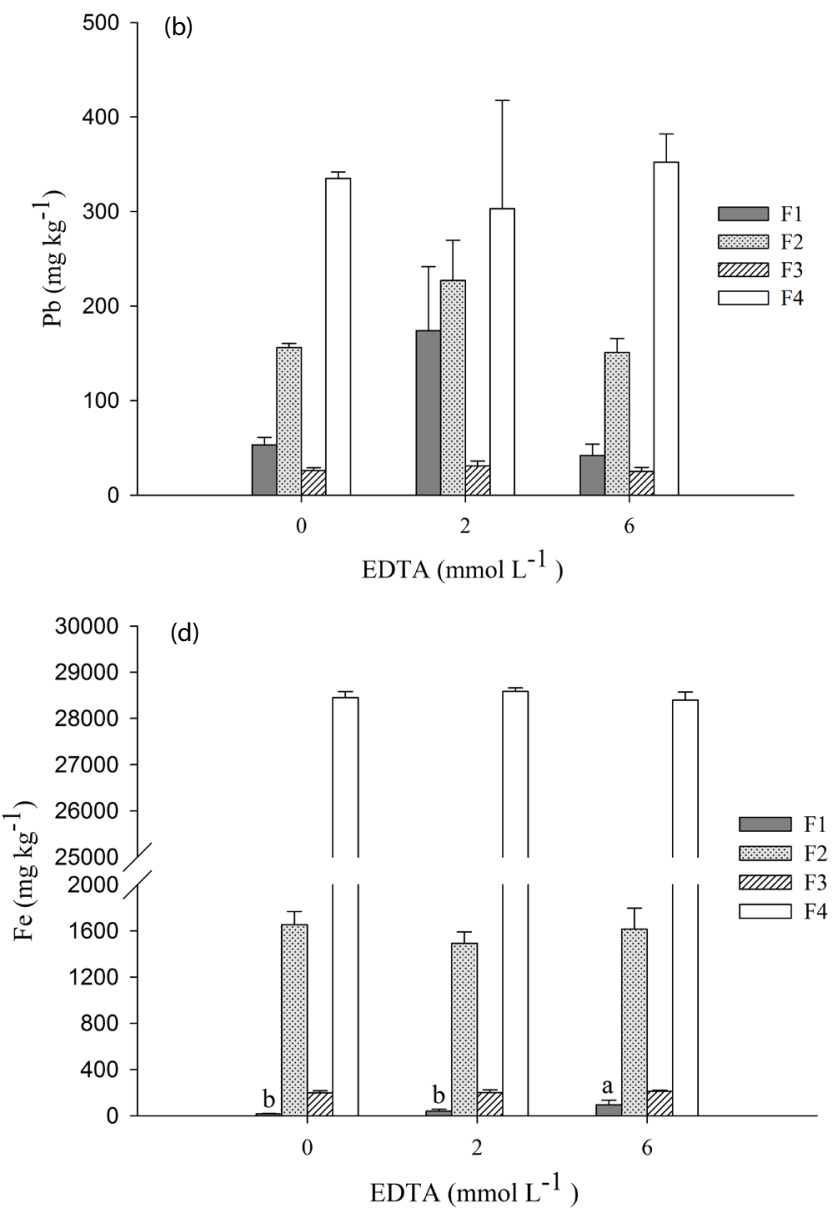

Figure 1. Geochemical fractionation of barium (a), lead (b), manganese (c), and iron (d), with and without EDTA addition. ${ }^{*}$ Standard deviations lower than $20 \%$ of the average value are not represented. 
Table 1. Dry matter production of the different vegetative parts of Cordia africana.

\begin{tabular}{|c|c|c|c|c|c|}
\hline \multirow{2}{*}{ Treatments } & \multicolumn{5}{|c|}{ Dry weight (grams per pot) } \\
\hline & Leaves & Stems & Root & Shoot & Whole plant \\
\hline Control & $\begin{array}{l}15.73^{\mathrm{NS}} \\
( \pm 0.6)\end{array}$ & $\begin{array}{l}25.40^{\mathrm{NS}} \\
( \pm 3.0)\end{array}$ & $\begin{array}{l}31.53^{\mathrm{NS}} \\
( \pm 35.0)\end{array}$ & $\begin{array}{l}41.13^{\mathrm{NS}} \\
( \pm 2.8)\end{array}$ & $\begin{array}{c}113.79 \mathrm{~A} \\
( \pm 4.7)\end{array}$ \\
\hline $2 \mathrm{mmol} \mathrm{L}^{-1} \mathrm{EDTA}$ & $\begin{array}{l}15.79^{\mathrm{NS}} \\
( \pm 1.5)\end{array}$ & $\begin{array}{l}25.22 \mathrm{NS} \\
( \pm 2.1)\end{array}$ & $\begin{array}{c}26.95^{\mathrm{NS}} \\
( \pm 2.9)\end{array}$ & $\begin{array}{l}41.01^{\mathrm{NS}} \\
( \pm 2.0)\end{array}$ & $\begin{array}{c}108.97 \mathrm{AB} \\
( \pm 2.9)\end{array}$ \\
\hline $6 \mathrm{mmol} \mathrm{L}{ }^{-1} \mathrm{EDTA}$ & $\begin{array}{l}12.22^{\mathrm{NS}} \\
( \pm 2.3)\end{array}$ & $\begin{array}{l}20.55^{\mathrm{NS}} \\
( \pm 2.7)\end{array}$ & $\begin{array}{l}24.05^{\mathrm{NS}} \\
( \pm 3.1)\end{array}$ & $\begin{array}{l}33.77^{\mathrm{NS}} \\
( \pm 4.1)\end{array}$ & $\begin{array}{l}90.59 \mathrm{~B} \\
( \pm 6.8)\end{array}$ \\
\hline
\end{tabular}

Values followed by different letters within the same column are significantly different according to Tukey's test at $\mathrm{p}<0.05$. NS: nonsignificant.

EDTA effectively promoted lead, iron, and manganese uptake and translocation into the C. africana leaves, but not barium uptake, for which no significant differences in leaf concentrations were observed between treatments (Table 2). This may be explained by the low solubility of barite $\left(\mathrm{BaSO}_{4}\right)$. However, the stem and root barium concentrations were higher for the treatments with EDTA addition than for the control treatment. The observed barium concentrations, which were higher than $500 \mathrm{mg} \mathrm{kg}^{-1}$ regardless of the presence of EDTA, showed a high capacity of C. africana for barium extraction. Pichtel et al. (2000) studied 14 plants, and all had insignificant barium uptake.
Few studies have found barium concentrations within the range considered normal in plant tissues. However, values between 90 and $106 \mathrm{mg} \mathrm{kg}^{-1}$ were found in corn plants grown in soil treated with sewage sludge (Nogueira et al., 2010) as were values up to $4970 \mathrm{mg} \mathrm{kg}^{-1}$ in soybean grown hydroponically (Suwa et al., 2008).

Except for barium, the leaf metal concentrations were higher for treatments receiving EDTA. Low EDTA concentrations increase the solubilization of metals present in soil, which may cause plant toxicity (Neugschwandtner et al., 2008; Santos et al., 2006). Thus, the observed toxicity symptoms may have been caused by lead and/or EDTA toxicity.

Table 2. Average metal concentration $\left(\mathrm{mg} \mathrm{kg}^{-1}\right)$ in the leaves, stems, and roots of Cordia africana for the three treatments.

\begin{tabular}{|c|c|c|c|c|c|c|c|c|c|}
\hline \multirow{2}{*}{ Metal } & \multicolumn{3}{|c|}{ Leaves } & \multicolumn{3}{|c|}{ Stems } & \multicolumn{3}{|c|}{ Roots } \\
\hline & 0 & 2 & 6 & 0 & 2 & 6 & 0 & 2 & 6 \\
\hline $\mathrm{Ba}$ & $\begin{array}{c}583^{\mathrm{NS}} \\
( \pm 77.8)\end{array}$ & $\begin{array}{c}602^{\mathrm{NS}} \\
( \pm 0.0)\end{array}$ & $\begin{array}{l}515^{\mathrm{NS}} \\
( \pm 0.0)\end{array}$ & $\begin{array}{c}178^{\mathrm{NS}} \\
( \pm 0.0)\end{array}$ & $\begin{array}{c}205^{\mathrm{NS}} \\
( \pm 0.0)\end{array}$ & $\begin{array}{c}234^{\mathrm{NS}} \\
( \pm 0.0)\end{array}$ & $\begin{array}{c}319 \mathrm{~B} \\
( \pm 0.0)\end{array}$ & $\begin{array}{l}517 \mathrm{AB} \\
( \pm 0.0)\end{array}$ & $\begin{array}{c}597 \mathrm{~A} \\
( \pm 0.0)\end{array}$ \\
\hline $\mathrm{Pb}$ & nd & $\begin{array}{c}207 \mathrm{~A} \\
( \pm 0.0)\end{array}$ & $\begin{array}{c}183 \mathrm{~A} \\
( \pm 0.0)\end{array}$ & nd & $\begin{array}{c}2.1 \mathrm{~B} \\
( \pm 0.0)\end{array}$ & $\begin{array}{c}32 \mathrm{~A} \\
( \pm 0.0)\end{array}$ & $\begin{array}{c}37 \mathrm{~B} \\
( \pm 0.0)\end{array}$ & $\begin{array}{c}48 \mathrm{~B} \\
( \pm 0.0)\end{array}$ & $\begin{array}{c}100 \mathrm{~A} \\
( \pm 0.0)\end{array}$ \\
\hline $\mathrm{Fe}$ & $\begin{array}{c}403 \mathrm{~B} \\
( \pm 113.4)\end{array}$ & $\begin{array}{c}627 \mathrm{~B} \\
( \pm 0.0)\end{array}$ & $\begin{array}{l}2029 \mathrm{~A} \\
( \pm 0.0)\end{array}$ & $\begin{array}{c}80 \mathrm{~A} \\
( \pm 0.0)\end{array}$ & $\begin{array}{c}54 \mathrm{~B} \\
( \pm 0.0)\end{array}$ & $\begin{array}{c}94 \mathrm{~A} \\
( \pm 0.0)\end{array}$ & $\begin{array}{l}4297^{\mathrm{NS}} \\
( \pm 0.0)\end{array}$ & $\begin{array}{l}4063^{\mathrm{NS}} \\
( \pm 0.0)\end{array}$ & $\begin{array}{l}3057^{\mathrm{NS}} \\
( \pm 0.0)\end{array}$ \\
\hline $\mathrm{Mn}$ & $\begin{array}{c}126 \mathrm{~B} \\
( \pm 18.3)\end{array}$ & $\begin{array}{c}178 \mathrm{~B} \\
( \pm 60.4)\end{array}$ & $\begin{array}{c}472 \mathrm{~A} \\
( \pm 200.9)\end{array}$ & $\begin{array}{c}9 \mathrm{~B} \\
( \pm 0.7)\end{array}$ & $\begin{array}{c}7 \mathrm{~B} \\
( \pm 0.8)\end{array}$ & $\begin{array}{c}43 \mathrm{~A} \\
( \pm 23.8)\end{array}$ & $\begin{array}{c}153 \mathrm{~B} \\
( \pm 35.0)\end{array}$ & $\begin{array}{c}98 \mathrm{~B} \\
( \pm 2.0)\end{array}$ & $\begin{array}{c}221 \mathrm{~A} \\
( \pm 40.0)\end{array}$ \\
\hline
\end{tabular}

Values followed by different letters within the same row were significantly different according to Tukey's test, at $p \leq 0.05$, for each plant part. NS: nonsignificant. 
No significant differences were found for the quantity of the accumulated barium in the leaves and stems of C. africana (Table 3). However, the quantity of the accumulated barium in the roots was significantly higher for the EDTA treatments; that is, the quantity of the accumulated barium was higher in the presence of EDTA. This was also observed for iron in the roots. The induction of heavy metal uptake by roots was also observed by Doumett et al. (2008). However, the highest lead and manganese accumulation was observed in leaves for the treatments with EDTA. Santos et al. (2006) cite several studies reporting increased heavy metal concentrations in leaves due to the presence of EDTA. This is a concern because C. africana is a deciduous plant, and the shedding of its leaves would return the metals to the soil via leaf degradation. Furthermore, this could spread the contamination (Lorenzi et al., 2003). Pichtel et al. (2000) mentions this concern with leaf shedding and dispersal in bioremediation areas. Considering only leaves, which are shed and dispersed, and more environmentally important, the TI was $0,72.3$, and $55.0 \%$ for lead and 58.1, 51.1 , and $43.7 \%$ for barium for the same sequence of treatments. Overall, the TI for lead, iron, and manganese increased with EDTA application (Table 4).

Table 3. Accumulated quantities (mg) of heavy metals in leaves, branches, and roots of Cordia africana for the three treatments.

\begin{tabular}{|c|c|c|c|c|c|c|c|c|c|}
\hline \multirow{2}{*}{ Metal } & \multicolumn{3}{|c|}{ Leaves } & \multicolumn{3}{|c|}{ Stems } & \multicolumn{3}{|c|}{ Roots } \\
\hline & 0 & 2 & 6 & 0 & 2 & 6 & 0 & 2 & 6 \\
\hline $\mathrm{Ba}$ & $\begin{array}{c}9.2 \mathrm{~A} \\
( \pm 1.3)\end{array}$ & $\begin{array}{c}9.5 \mathrm{~A} \\
( \pm 0.5)\end{array}$ & $\begin{array}{c}6.8 \mathrm{~B} \\
( \pm 1.4)\end{array}$ & $\begin{array}{c}4.3^{\mathrm{NS}} \\
( \pm 2.4)\end{array}$ & $\begin{array}{c}5.1^{\mathrm{NS}} \\
( \pm 2.5)\end{array}$ & $\begin{array}{c}5.3^{\mathrm{NS}} \\
( \pm 1.2)\end{array}$ & $\begin{array}{c}9.7 \mathrm{~B} \\
( \pm 1.9)\end{array}$ & $\begin{array}{c}13.9 \mathrm{~A} \\
( \pm 2.0)\end{array}$ & $\begin{array}{c}15.5 \mathrm{~A} \\
( \pm 1.6)\end{array}$ \\
\hline $\mathrm{Pb}$ & nd & $\begin{array}{c}3.3 \mathrm{~A} \\
( \pm 0.6)\end{array}$ & $\begin{array}{c}2.3 \mathrm{~A} \\
( \pm 0.4)\end{array}$ & nd & $\begin{array}{c}0.05^{\mathrm{NS}} \\
( \pm 0.0)\end{array}$ & $\begin{array}{c}0.73^{\mathrm{NS}} \\
( \pm 0.9)\end{array}$ & $\begin{array}{l}1.12^{\mathrm{NS}} \\
( \pm 0.5)\end{array}$ & $\begin{array}{l}1.27^{\mathrm{NS}} \\
( \pm 0.2)\end{array}$ & $\begin{array}{c}2.5^{\mathrm{NS}} \\
( \pm 1.3)\end{array}$ \\
\hline $\mathrm{Fe}$ & $\begin{array}{c}6.4 \mathrm{~B} \\
( \pm 2.0)\end{array}$ & $\begin{array}{c}10 \mathrm{~B} \\
( \pm 3.4)\end{array}$ & $\begin{array}{c}25 \mathrm{~A} \\
( \pm 7.4)\end{array}$ & $\begin{array}{c}2.0 \mathrm{~A} \\
( \pm 0.2)\end{array}$ & $\begin{array}{c}1.4 \mathrm{~B} \\
( \pm 0.2)\end{array}$ & $\begin{array}{c}2.1 \mathrm{~A} \\
( \pm 0.2)\end{array}$ & $\begin{array}{c}134 \mathrm{~A} \\
( \pm 24.5)\end{array}$ & $\begin{array}{c}108 \mathrm{AB} \\
( \pm 15.1)\end{array}$ & $\begin{array}{c}79 \mathrm{~B} \\
( \pm 13.7)\end{array}$ \\
\hline $\mathrm{Mn}$ & $\begin{array}{c}2 . \mathrm{B} \\
( \pm 0.4)\end{array}$ & $\begin{array}{c}2.8 \mathrm{~B} \\
( \pm 0.9)\end{array}$ & $\begin{array}{c}6.0 \mathrm{~A} \\
( \pm 1.6)\end{array}$ & $\begin{array}{c}0.2 \mathrm{~B} \\
( \pm 0.0)\end{array}$ & $\begin{array}{c}0.2 \mathrm{~B} \\
( \pm 0.0)\end{array}$ & $\begin{array}{c}1.0 \mathrm{~A} \\
( \pm 0.6)\end{array}$ & $\begin{array}{c}4.9 \mathrm{~A} \\
( \pm 1.3)\end{array}$ & $\begin{array}{c}2.7 \mathrm{~B} \\
( \pm 0.3)\end{array}$ & $\begin{array}{c}5.7 \mathrm{~A} \\
( \pm 0.9)\end{array}$ \\
\hline
\end{tabular}

Values followed by different letters within the same row were significantly different according to Tukey's test at $\mathrm{p} \leq 0.05$ for each plant part. NS: nonsignificant.

Table 4. Translocation index (TI) in Cordia africana plants (average).

\begin{tabular}{|c|c|c|c|c|}
\hline EDTA & $\mathbf{B a}$ & $\mathbf{P b}$ & $\mathrm{Fe}$ & Mn \\
\hline$\left(\mathrm{mmol} \mathrm{L}^{-1}\right)$ & & 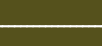 & 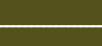 & \\
\hline 0 & $\begin{array}{c}39.5 \\
( \pm 11.2)\end{array}$ & $\begin{array}{c}0.0 \\
( \pm 0.0)\end{array}$ & $\begin{array}{c}4.5 \\
( \pm 1.4)\end{array}$ & $\begin{array}{c}28.1 \\
( \pm 9.0)\end{array}$ \\
\hline 2 & $\begin{array}{c}33.3 \\
( \pm 4.2)\end{array}$ & $\begin{array}{c}71.2 \\
( \pm 5.6)\end{array}$ & $\begin{array}{c}8.3 \\
( \pm 3.0)\end{array}$ & $\begin{array}{c}49.7 \\
( \pm 9.7)\end{array}$ \\
\hline 6 & $\begin{array}{c}24.6 \\
( \pm 4.6)\end{array}$ & $\begin{array}{c}41.9 \\
( \pm 7.7)\end{array}$ & $\begin{array}{c}23.8 \\
( \pm 8.0)\end{array}$ & $\begin{array}{c}47.0 \\
( \pm 7.5)\end{array}$ \\
\hline
\end{tabular}


The efficiency of phytoextraction was evaluated by calculating the remediation factor (RF), according to the following equation:

$\mathrm{RF}=[\mathrm{M}($ plant $) \times$ plant weight $/ \mathrm{M}($ soil $) \times$ pot weight $] \times 100$

Where $\mathrm{M}$ is the concentration of the contaminant metal.

The RF of C. africana for barium was $0.05 \%$ for the control, $0.05 \%$ for the split application, and $0.045 \%$ for the single application of EDTA.

However, for lead, the values were 0 for the control, $0.15 \%$ for the split application, and $0.13 \%$ for the single application of EDTA. These values are lower than the $1 \%$ considered to be necessary by Huang et al. (1997) for phytoextraction to be economically viable.

The accumulated quantity of the contaminant metals in the vegetative plant parts showed C. africana cannot be considered a phytoextractor for these metals. However, it can be used as a phytostabilizer.

Remediation of the studied soil through metal removal using phytoextraction was not effective for the studied metals, as low heavy metal accumulation occurred in the plant, and low remediation factor values were observed. However, $C$. africana was observed to be an adequate soil-stabilizing agent because it grew well in soil with high concentrations of barium, lead, iron, and manganese and showed a tolerance to EDTA.

\section{CONCLUSIONS}

EDTA increased the accumulated quantity and TI for lead, manganese, and iron in C. africana and also increased the barium concentrations in C. africana roots but not its translocation to the shoot.

The low remediation factor values contraindicate the use of C. africana in phytoextraction. However, the tolerance of C. africana to heavy metals and EDTA toxicity, under the studied conditions, indicates that this plant can be used for phytostabilization of contaminated areas.

\section{ACKNOWLEDGEMENTS}

The authors are grateful to the Universidade Federal Rural do Rio de Janeiro (UFRRJ), the Fundação de Amparo à Pesquisa do Estado do Rio de Janeiro (FAPERJ) and the Conselho Nacional de Desenvolvimento Científico e Tecnológico $(\mathrm{CNPq})$ for their financial support.

\section{SUBMISSION STATUS}

Received: 9 Aug. 2017

Accepted: 31 July 2018

Associate editor: Marcos Gervásio Pereira (iD

\section{CORRESPONDENCE TO}

\section{Erica Souto Abreu Lima}

Universidade Federal Rural do Rio de Janeiro (UFRRJ), Rodovia BR 465, km 7, s/n, CEP 23890-000, Seropédica, RJ, Brasil

e-mail: ericaabreulima@gmail.com

\section{REFERENCES}

Abichequer AD, Bohnen H. Eficiência de absorção, translocação e utilização de fósforo por variedades de trigo. Revista Brasileira de Ciência do Solo 1998; 22(1): 21-26. 10.1590/S010006831998000100003

ANDRADE, André Fernão Martins de2014Andrade AFM, Amaral Sobrinho NMB, Santos FS, Magalhães MOL, Tolón-Becerra A, Lima LS. EDTA-induced phytoextraction of lead and barium by brachiaria (B. decumbens cv. Basilisk) in soil contaminated by oil exploration drilling waste. Acta Scientiarum Agronomy 2014; 36(4): 495-500. 10.4025/actasciagron.v36i4.18172

Bauder TA, Barbarick KA, Ippolito JA, Shanahan JF, Ayers PD. Soil properties affecting wheat yields following drilling-fluid application. Journal of Environmental Quality 2005; 34(5): 1687-1696. 10.2134/ jeq2004.0384

Caenn R, Darley HCH, Gray GR. Composition and properties of drilling and completion fluids. 6th ed. Elsevier: Oxford; 2011.

Donagema GK, Campos DVB, Calderano SB, Teixeira WG, Viana JHM. Manual de métodos de análise de solos. 2nd ed. Rio de Janeiro: Embrapa Solos; 2011.

Doumett S, Lamperi L, Checchini L, Azzarello E, Mugnai S, Mancuso $S$ et al. Heavy metal distribution between contaminated soil and Paulownia tomentosa, in a pilot-scale assisted phytoremediation study: influence of different complexing agents. Chemosphere 2008; 72(10): 1481-1490. 10.1016/j. chemosphere.2008.04.083

Evangelou WHM, Ebel M, Schaeffer A. Chelate assisted phytoextraction of heavy metals from soil: effect, mechanism toxicity and fate of chelating agents. Chemosphere 2007; 68(6): 989-1003. 10.1016/j.chemosphere.2007.01.062

Huang JW, Chen J, Berti WR. Phytoremediation of Pbcontaminated soils: role of synthetic chelates in lead phytoextraction. Environmental Science \& Technology 1997; 31(3): 800-805. 10.1021/es9604828

Lima ESA, Amaral Sobrinho NMB, Magalhães MOL, Guedes JN, Zonta E. Absorção de bário por plantas de arroz (Oryza sativa L.) e mobilidade em solo tratado com baritina sob diferentes condições de potencial redox. Química Nova 2012; 35(9): 1746-1751. 10.1590/ S0100-40422012000900008

Lorenzi H, Souza HM, Torres MAV, Bacher LB. Árvores exóticas no Brasil: madeireiras, ornamentais e aromáticas. Nova Odessa: Instituto Plantarum; 2003.

Ma YB, Uren NC. Transformations of heavy metals added to soil: application of a new sequential extraction procedure. Geoderma 1998; 84(1): 157-168. 10.1016/S0016-7061(97)00126-2

Magalhães MOL, Amaral Sobrinho NMB, Zonta E, Simões BF, Mattos AG, Tolón-Becerra A et al. The effects of oil well drill cuttings 
on soil and rice plant development (Oryza sativa) under two redox conditions. Bulletin of Environmental Contamination and Toxicology 2014; 92(3): 311-316. 10.1007/s00128-014-1196-7

Neugschwandtner WR, Tlustos P, Komárek M, Száková J. Phytoextraction of $\mathrm{Pb}$ and $\mathrm{Cd}$ from a contaminated agricultural soil using different EDTA application regimes: laboratory versus field scale measures of efficiency. Geoderma 2008; 144(3-4): 446-454. 10.1016/j.geoderma.2007.11.021

Nogueira TAR, Demelo WJ, Fonseca IM, Marques MO, He Z. Barium uptake by maize plants as effected by sewage sludge in long-term field study. Journal of Hazardous Materials 2010; 181(1-3): 11481157. 10.1016/j.jhazmat.2010.05.138

Pereira ACC, Amaral Sobrinho NMB, Sampaio J Jr, Oliveira JA, Santos FS, Mazur N. Comportamento da Cordia africana Lam. cultivada em solo contaminado por metais pesados e tratado com materiais amenizantes. Ciência Florestal 2013; 23(3): 329-336. $10.5902 / 1980509810544$

Pereira ACC, Amaral Sobrinho NMB, Santos FS, Guedes JN. Concentração de metais pesados em espécies arbóreas utilizadas para revegetação de área contaminada. Revista Ciência Agronômica 2012; 43(4): 641-647. 10.1590/S1806-66902012000400004

Pereira BFF, Abreu CA, Herpin U, Abreu MF, Berto RS. Phytoremediation of lead by jack beans on a Rhodic Hapludox amended with EDTA. Scientia Agricola 2010; 67(3): 308-318. 10.1590/S0103-90162010000300009

Pichtel J, Kuroiwa K, Sawyerr HT. Distribution of Pb, Cd and Ba in soils and plants of two contaminated sites. Environmental Pollution 2000; 110(1): 171-178. 10.1016/S0269-7491(99)00272-9

Rauret G, López-Sánchez JF, Sahuquillo A, Rubio R, Davidson $\mathrm{C}$, Ure A et al. Improvement of the BCR three step sequential extraction procedure prior to the certification of new sediment and soil reference materials. Journal of Environmental Monitoring 1999; (1): 57-61. 10.1039/A807854H

Sampaio J Jr, Amaral Sobrinho NMB, Zonta E, Magalhães MOL. Barium and sodium in sunflower plants cultivated in soil treated with wastes of drilling of oil well. Revista Brasileira de Engenharia Agrícola e Ambiental 2015; 19(11): 1100-1106. 10.1590/1807-1929/ agriambi.v19n11p1100-1106

Santos FS, Hernández-Allica J, Becerril MJ, Amaral Sobrinho N, Mazur N, Garbisu C. Chelate-induced phytoextraction of metal polluted soils with Brachiaria decumbens. Chemosphere 2006; 65(1): 43-50. 10.1016/j.chemosphere.2006.03.012

Silveira ML, Alleoni LRF, O’Connor GA, Chang AC. Heavy metal sequential extraction methods: a modification for tropical soils. Chemosphere 2006; 64(11): 1929-1938. 10.1016/j. chemosphere.2006.01.018

Sposito G. The chemistry of soils. 2nd ed. New York: Oxford University Press; 2008.

Suwa R, Analuddin K, Khan MNI, Hagihara A. Structure and productivity along a tree height gradient in a Kandelia obovata mangrove forest in the Manko Wetland, Okinawa Island, Japan. Wetlands Ecology and Management 2008; 16(4): 331-343. 10.1007/ s11273-007-9071-5

Ure AM, Quevauvillers P, Muntau H, Griepink B. Speciation of heavy metals in soils and sediments: an account of the improvement and harmonization of extraction techniques undertaken under the auspices of the BCR of the Commission of the European Communities. International Journal of Environmental Analytical Chemistry 1993; 51(1-4): 135-151. 10.1080/03067319308027619

Vaxevanidou K, Papassiopi N, Paspaliaris I. Removal of heavy metals and arsenic from contaminated soils using bioremediation and chelant extraction techniques. Chemosphere 2008; 70(8): 1329-1339. 10.1016/j.chemosphere.2007.10.025

Xia W, Gao H, Wang X, Chunhua Z, Liu Y, Fan T et al. Application of EDTA decontamination on soils affected by mining activities and impact of treatment on the geochemical partition of metal contaminants. Journal of Hazardous Materials 2009; 164(2-3): 936-940. 10.1016/j.jhazmat.2008.08.092 